М.I.Хилько,

доктор філософських наук, професор кафедри політології

КНУ імені Тараса Шевченка

\title{
КЛАСИФІКАЦІЯ ПРІОРИТЕТІВ ПОЛІТИКИ ЕКОБЕЗПЕЧНОГО РОЗВИТКУ
}

Зважаючи на велику різноманітність екологічних проблем, суспільство змушене встановлювати черговість їх вирішення і відповідно - вкладення коштів. Виходячи з низької якості природних екосистем України, необхідності значних витрат на природоохоронні програми в умовах тотальної соціально-економічної кризи, визначення пріоритетних напрямків для відпрацювання реалістичних, ефективних і економічно вигідних рішень є справою необхідною.

Сподівання на «рятівний для природи» соціалістичний лад, який визнає навколишнє середовище суспільним надбанням, не виправдались. Природні ресурси виявились у розпорядженні відомств, безвідповідальних чиновників. Це призвело до небувалих екологічних втрат. Але і приватна власність на природні багатства не обіцяє нічого хорошого. У цьому разі природа розглядається як засіб особистої наживи. «Просто власник зацікавлений у найповнішій з максимальною вигодою... експлуатації природних... трудових... інтелектуальних ресурсів. В принципі до такої системи експлуатації можуть прийти і відомства, і групи чиновників» [2, 33].

Сучасна могутня держава - США - 3 високим науково-технічним рівнем не уникла екологічних криз. Де в чому вона навіть перевершила інші країни, ставши одним 3 найбільш споживацьких суспільств. I якщо власні природні багатства США навчились більш-менш зберігати, то робиться це значною мірою за рахунок інших регіонів планети. Взагалі для сучасного світу характерна своєрідна форма експлуатації - екологічна. «Слаборозвинуті країни змушені розраховуватися за економічну допомогу і природними ресурсами, і робочою силою, і здоров'ям громадян - внаслідок створення на їх територіях екологічно шкідливих виробництв (згадаймо хоча б катастрофу на хімічному заводі в індійському місті Бхопалі, яка забрала 2000 людських життів)» [2, 32].

Екологізація технологій, економія енергетичних та інших ре- 
сурсів, утилізація відходів, екологічна освіта - подібні заходи дають змогу технічно розвинутим державам пом'якшувати екологічну ситуацію. Але радикально оздоровити іiі, подолати загальну екологічну кризу сучасної технічної цивілізації таким шляхом навряд чи вдасться.

При всій різноманітності сучасних політичних систем, соціальноекономічних структур вони зберігають єдність, мабуть, у головному: залишаються суспільствами споживання, які виснажують і забруднюють середовище життя, біосферу і формують техногенну людину. Інакше і бути не може. Техніка «творить» природу і людину за своїм образом і подобою, перетворюючи останню з мети на засіб. Механічна система техніки покликана підпорядковувати і дедалі інтенсивніше експлуатувати навколишнє середовище, а ресурси біосфери досить обмежені, тоді як могутність і можливості техніки зростають практично безмежно. Отже, сучасна технічна цивілізація відрізняється від попередніх лише тим, що має унікальні можливості зруйнувати біосферу: або за лічені хвилини (атомна війна), або за кілька десятиліть (продовження екологічної експансії) $[1,88]$.

Надії на «безвідходну технологію» здаються малоймовірними, як і на вічні двигуни. При цьому не враховуються ні втрати матеріальної сировини, ні зайняті промисловістю і містами території, ні виснаження грунтів, ні теплове забруднення. Коротше кажучи, вчені - оптимісти і ентузіасти - навчились робити підрахунки, які підтверджують їх думку, незважаючи на «реальність». А слід було б визнати: ми й досі не знаємо, як можна задовольнити зростаючі матеріальні потреби зростаючої кількості людей на Землі, не руйнуючи і не забруднюючи біосферу.

Отже, людство прямує до екологічної катастрофи? А вона, звичайно, не може не супроводжуватися загостренням міжнародної напруженості. Тобто становище справді здається вельми песимістичним, якщо не безнадійним. А коли обіцяють, що наука неодмінно знайде вихід з глухого кута, мимоволі згадується: у нашому столітті наука найбільш успішно знаходила немислимі раніше спроби масового знищення людей i, взагалі, живого на Землі. I все ж, без надії життя людини жахливе.

Виявляється, що характер взаємодії людини, суспільства, природи та наслідків цієї взаємодії багато в чому визначається системою обраних пріоритетів. Питання про пріоритети водночас і просте, і складне. Над цією проблемою давно вже працюють учені й 
спеціалісти, проте єдності досягти їм поки що не вдалося.

Пріоритети визначаються за метою: 1) пріоритет суспільства, ідеальної держави; 2) пріоритет особистості; 3) пріоритет природи перед суспільством і особистістю; за рівнями: 1) глобальні; 2) регіональні; 3) національно-державні; ситуаційні: як реакція на аварії, катастрофи, реальні чи ті, щуо насуваються.

У недалекому соціалістичному минулому метою проголошувалася побудова ідеальної держави, якою вважали таку, де кожен громадянин тотожний у своїх інтересах і вчинках суспільному цілому. Людина в ній не $є$ особистістю, не претендує на індивідуальну самоцінність і автономність у вчинках. Засобами для створення ідеального суспільства загального доброчинства і справедливості виступали і кожна конкретна людина, і вся природа. В тій чи іншій формі така система пріоритетів дуже поширена. Початок вона бере від Платона і випробовувати іiі на собі довелось значній частині людства. У визначенні пріоритетів екологічної політики основну роль відіграють потреби суспільства, тобто вся сукупність установок, яку часто називають соціальним замовленням. Доцільність цих установок визначається соціально-економічною природою суспільства, характером панівного ладу і рівнем культури.

Нерідко практикується визначення пріоритетів 3 антропоцентристських позицій - людина понад усе. Пріоритет особистості, на благо якої, за ідеєю, повинна діяти держава, був дуже популярним у країнах ринкової економіки, а віднедавна - і в посткомуністичних країнах.

Здавалося б, такий принцип дуже привабливий, прогресивний. Залишається тільки навести «певний порядок» у розподілі заходів. Хіба благо особистості, кожної конкретної людини - не вища цінність? Адже реально існує, живе, радіючи і страждаючи, мислячи і люблячи, кожен $з$ людей сам і помирає «особисто». Існування будь-яких організацій має виправдання лише тією мірою, якою вони здатні розкрити можливості і прагнення зробити життя кожного більш яскравим, повним, гідним і щасливим.

Такий підхід переконливий. Проте є у ньому одна слабка ланка, яка може стати дуже сумнівною. Вона проникнута обожнюванням людини як такої, як споживача і творця (заради споживання) матеріальних цінностей. Природа, що створила ії як істоту тілесну і духовну, тепер зведена до становища байдужого, безглуздого, бездуховного «середовища проживання». Вона в цьому контексті постає 
мертвим космічним тілом в закляклому середовищі, в якому юрмища живих організмів. Серед них є примітивні, а є вищі створіння, покликані підкорювати і споживати все, що тільки їм доступне за допомогою технічних пристроїв, наукових розробок, організацій. Усе - в людині, все - для людини!

Це позиція підкорювача. То невже заради цього скороминущого і жалюгідного тріумфу споживача творилася вся геологічна історія? $\mathrm{Hi}$, безумовно, все це здійснювалося і здійснюється саме по собі, безвідносно до людини. Але сама людина покликана надати тілам і явищам природи смисл, охопити їх і освоїти спершу у своїй свідомості, а потім - у реальній дійсності. У цьому суть людини розумної, творящої. Тільки от виникає сумнів: як і коли все це може реалізуватися, коли вже зараз поширюється глобальна екологічна криза, вихід з якої не знайдений навіть умоглядно. Сподіватися на краще не варто, адже з такою надією стільки знищено людей і загублено тварин і рослин, що пора вже навчитися відрізняти ілюзії від реальності і оцінити страшну небезпеку навіть для нинішніх, а не тільки для майбутніх поколінь.

Відзначимо, що антропоцентристські настрої дуже стійкі, і кинутий поборникам охорони природи докір - «про людину забули» знайде співчуття в будь-якій аудиторії. У спаплюженому варіанті природа взагалі не згадується, оскільки, виходить, оберігати треба не природу, а «навколишнє середовище» $[3,16]$.

Не доводиться сперечатися, що вся природоохоронна діяльність так чи інакше стосується інтересів людини. Але в чому вони, ці інтереси? Будь-яка людина зацікавлена в тому, щоб дихати чистим повітрям, мати зручне житло, достатнє харчування і медичну допомогу. Та чи сприяє всьому цьому, скажімо, знищення тропічних лісів, які постачають атмосфері кисень і деревина яких іде, зокрема, на шикарні кабінети політичних лідерів (згадаймо епізод з опорядженням махагонієвим деревом кабінету М. Тетчер, що набув широкого розголосу)? Чи в інтересах людини було пустити на зрошення води, що живили Арал, i, зрештою, поставити під загрозу життя десятків мільйонів людей? А скількох лікарських препаратів недорахуються наші потомки в результаті втрати біологічної різноманітності?

Отже, будь-який вплив на природне середовище викликає відповідну реакцію, яка в більшості випадків стає несприятливою для людини. При цьому захворювання, пов'язані з забрудненням середовища, - лише надводна частина айсберга. Більш суттєві впливи 
техногенних чинників, які поволі перебудовують генофонд людської популяції. I, нарешті, «у людини є потреба не тільки в матеріальному, а й духовному комфорті. Потрібна грунтовна... ідеологічна обробка для того, щоб зі спокійною совістю спостерігати загибель природи» [3, 16-17].

Нерідко в системі пріоритетів сама природа визнається найвищою иінністю буття. Кожна конкретна особистість, будь-яке товариство, суспільство і все людство вважаються одним із засобів саморозвитку біосфери, галактики, космосу. Суть, кожної людини і всього людства визначається ступенем причетності до цих або їм подібних систем.

Такі пріоритети відповідають багатьом, якщо не всім, регіональним ідеологіям, які визнають над людиною владу, велич природи або надрозум Всевишнього. Релігійні ідеї, навіть найфантастичніші, відображують у своєрідній формі досвід спілкування з природою сотень поколінь, різних племен і народів. I якщо виникне можливість поєднати його з висновками наукових досліджень, досвідом технічної цивілізації, подібний синтез розумно вважати наближеним до об'єктивної реальності. (Хоча зберігаються традиції відступу від неї або в ілюзорні світи фантастичних домислів, або в безплідну схоластику наукових схематизацій) $[2,35]$.

Як відомо, в усіх племенах, навіть 3 найпримітивнішою матеріальною культурою, існували міфологічні, а пізніше - релігійні погляди та мистецтво. Чудові твори мистецтва, зокрема, малюнки, кроманьйонських мисливців (близько 20-30 тисячоліть тому). Така рання поява релігії та мистецтва свідчить, що це були не «надмірності розуму й почуттів», а надійні засоби у боротьбі за існування. Те, що релігійні фантазії можуть допомогти орієнтуватися в реальному світі - це факт, підтверджений історією людства.

Пояснень цьому існує декілька. Нагадаємо, що єдність релігійних поглядів згуртовує групи людей (племена, етноси, народи), дає можливість раціонально (нехай навіть і на ірраціональній основі) координувати їх дії. А ще релігійний світогляд допомагає обирати стратегію поведінки за браком інформації.

Стратегія взаємодії з природою, що уявлялась як розумний, одухотворений партнер, визначалась культурою вірувань (релігія), емоцій (мистецтво) і міркувань (філософія). Це давало можливість створювати не лише матеріальні цінності, а й науку. А коли симбіоз науки з технікою показав свої можливості в «підкоренні природи», 
оволодінні їі багатствами, взаємовідношення духовної і матеріальної культури принципово змінилися. Тепер уже виробництво матеріальних цінностей перетворилося на самоціль. Людина почала розглядати природу як сукупність мертвих і живих тіл, що пов'язані в механічну систему. Це - зліпок, бездушний лик - поза душею, свободою, любов'ю, життям, творенням $[2,36]$.

Справа ускладнюється принциповим неприйняттям ідеї одухотвореності земної природи, світобудови взагалі і утвердженням примату матеріальних цінностей над духовними, ідеології безносереднього виробника речей - над ідеологією творця ідей. Звичайно, існують різні прийоми і технічні засоби, які зменшують шкідливі впливи на середовище проживання, сповільнюють темпи забруднення і руйнування біосфери. Але одного цього надто мало для докорінної зміни ситуації. «Адже не тільки природа, а й сама людина, людська особистість, мікрокосмос перетворюються з найвищої духовної цінності у звичайний засіб виробництва» $[2,36]$.

Ідея про пріоритет природи перед особистістю і суспільством у різних формах присутня не лише в релігійних системах, а й у деяких філософських і наукових вченнях. Наприклад, А.Швейцер проголосив етику благоговіння перед живим, а В.Вернадський створив основи вчення про біосферу, галузь життя, що має якості організму, а не задубілої механічної системи. I якщо дійсно в найближчі роки пошириться етика благоговіння перед життям чи, скажемо м'якше, - етика розумного егоїзму, то це може стати початком нової ери. Від євангелій, написаних людьми, час переходити до найвеличнішої євангелії Природи (М. Ломоносов).

Потрібно усвідомити і затвердити методом наукових доказів наскільки це можливо - пріоритет природи, біосфери, життя: як верховенство цілого над частиною. Це не забуття людиною ії потреб, не приниження iii (бо принизливо виставляти іiі саме як пожадливого споживача матеріальних благ). Навпаки, усвідомлення причетності до вищого - на Землі й у Космосі - надає тлінному особистому існуванню смисл $[4,156]$.

Визнаючи примат природи на словах, що слід було б зробити для цього практично? Адже відомо, що які б світлі ідеали не сповідувала б людина, вони далеко не завжди зумовлюють правильні рішення, скажімо, щодо екологічних проблем. Так, цивілізація християнського середньовіччя Європи орієнтувалась на духовний світ людини, на високі моральні цінності, на визнання всемогутнього 
Бога, а завершилась ця епоха надзвичайно глибокою кризою релігійних і філософських ідей, моральних устоїв, а також значною шкодою, завданою природі.

Певно, що в економіці повинен здобути визнання і принщип екологічної рентабельності. Суть його в тому, що будь-які проекти, галузі виробництва, окремі підприємства, технічні системи, народне господарство в цілому повинні оцінюватися, зокрема, враховуючи ті екологічні зміни, які вони вносять у навколишнє середовище. Суспільству потрібен не лише «економічний» прибуток, який обчислюється у грошах, а реальний прибуток природи, або, інакше, економія природи.

Це означає - навчання у природи і прагнення продовжувати i розвивати саме іiі. Затоплюючи родючі землі, знищуючи ліси або моря, створюючи пустирі і т. ін., ми зменшуємо активність природних процесів, придушуємо життя, різко знижуємо біологічну продуктивність землі й акваторій, спрощуємо природні екосистеми. Отже, ми діємо всупереч законам розвитку біосфери, еволюції живих організмів. Коли на місці лісу виникає промрайон, це неприпустима втрата, бо екологічно нерентабельна, навіть якщо продукція цього підприємства і даватиме великі грошові прибутки [4, 157].

Будь-яка техніка і будь-яка технологія повинні бути максимально екологічними. Для найбільш небезпечних і «брудних» виробництв доцільно використовувати підземні порожнини: шахти, печери, покинуті гірські виробки. Пуста порода має перероблятися 3 користю або закладатися у відпрацьовані порожнини і т. ін.

Як же так: забути про власні потреби і обслуговувати природу, коли нам потрібно дедалі більше енергії, сировини, води, матеріалів, продуктів, одягу?! А якщо поставити собі питання іншим чином: «А навіщо нам усі ці потужні потоки енергії, надшвидкісні види транспорту, надпотужні гігантські механізми, розкішні автомобілі й багато-багато чого? Чи зробило все це життя сучасної людини чистішим, білыш гідним, радіснішим? Навряд чи. Нині людина більше працює на техніку, ніж техніка - на людину. Якщо раніше технічні системи можна було вважати придатком людини, то тепер здебільшого людина придаток техніки. Це обов'язкова плата за блага і зручності. Звідси урок, що, піклуючись про власний добробут і не зважаючи на потреби і принципи життя земної природи, ми дійшли до екологічної кризи. Судячи з усього, єдиний вихід 3 неї - рішуче змінити цей принцип: дбати про благо природи, яка 
створила і забезпечила наше життя, не зважати на власні нестримно зростаючі матеріальні потреби [2, 38-39].

Проте люди не настільки високо духовні, щоб піклуватися, насамперед, про «благо» природи. Для цього потрібен високий культурний потенціал, глибокі знання і переконання. Але й цього мало. Треба звільнити людину від принизливого панування над нею іiі власних продуктів, від недоброякісної інформації.

Тільки вільна і сильна людина здатна підкоритись природі, старанно осягаючи їі мудрість. Практично всі люди народжуються саме такими. Потрібні величезні зусилля, страшне викривлення буття, щоб перетворити їх на тупих обивателів, кар'єристів і т.ін. Сучасна людина надто приголомшена політизацією культури, вульгарністю, розвагами. А потрібні їй, насамперед, знання, краса, милосердя, усе те, щуо називається цінностями духовними. Тільки вони роблять ії людиною розумною $[2,39]$.

Така класифікація пріоритетів, звичайно, досить умовна. Проте це не єдино можливий підхід. Система «людина - середовище» може розглядатися і в іншому плані з відповідною розстановкою пріоритетів. Наприклад, пріоритети можуть визначатись ситуативно як у випадку землетрусів, екологічної катастрофи, що примушує відволікати сили і засоби від інших проблем. Проте довготривалі пріоритети грунтуються на наших уявленнях про природні й техногенні процеси та їх наслідки. Наприклад, викиди хлорфторвуглецю не привертали великої уваги до того часу, поки не виникло питання про їх участь у руйнуванні озонового шару. Таким чином, пріоритети залежать від наявного рівня знань $[3,17]$.

Пріоритети можуть відповідати просторово-часовим масштабам явищ. При цьому вищий рейтинг мають глобальні й необоротні процеси. Пріоритетність глобальних проблем зумовлена тим, що вони охоплюють усю біосферу, виявляються повсюдно, хоч, можливо, і з різною гостротою. Глобальні явища мають довготривалі, у багатьох випадках - необоротні наслідки. Глобальні кліматичні зміни мають циклічний характер, але повернення до початкового стану може відбуватися через сотні або тисячі років і ніколи не буде стовідсотковим за всіма параметрами. Кожен біологічний вид $\epsilon$ унікальним продуктом еволюції, і втрата його має необоротний характер. Вирішення глобальних проблем потребує узгоджених дій, які будуть ефективними лише в тому разі, якщо людство відчує себе єдиним цілим і подолає вузькість національно-державного мислення. 
На національному рівні нерідко виникають пріоритетні проблеми, пов'язані з географічними особливостями країни і спеціалізацією економіки. Так, у країнах Близького Сходу на першому місці стоїть проблема водних ресурсів, у Бразилії - збереження тропічних лісів. Поряд 3 очевидними існують проблеми, для з'ясування і оцінки яких необхідний спеціальний аналіз із використанням методів оцінки стану природних комплексів і прогнозування їх розвитку. Це стосується і України. Тут чимало прихованих проблем, які можуть перетворитись у пріоритетні найближчим часом. Одна 3 головних проблем полягає у перегляді суспільних позицій щодо природи на всіх рівнях, від найвищих законодавчих органів до неурядових організацій і окремих громадян.

Розглянемо специфіку пріоритетів екологічно безпечного розвитку на глобальному, регіональному і національно-державному рівнях.

Глобальні екологічні проблеми - це складний комплекс проблем природного і антропогенного походження, що динамічно змінюється. Багато 3 них становлять реальні екологічні загрози: зміна хімічного складу атмосфери і їі наслідки (зростання концентрації «парникових газів» і глобальне потепління, закислення навколишнього середовища та інше забруднення природних прісних вод, океанів i прибережних акваторій); знеліснення й опустелювання, ерозія грунтів, втрата родючості земель; ризик, пов'язаний з біотехнологією; виробництво, перевезення і застосування токсичних речовин: до цього долучаються різні погляди в різних країнах на забезпечення здоров’я і безпеки людини, а також передача країнам, які розвиваються, небезпечних технологій, що створює загрози населенню і т. ін.

Г.Марчук і К.Кондратьєв визначають чотири категорії загроз, пов'язаних зі змінами в навколишньому середовищі: 1) безпосередні загрози існуванню людини (голод, хвороби, радіація та ін.); 2) загрози територіям (опустелювання, підвищення рівня океану, транскордонне перенесення забруднень, вилучання стоку рік країнами, розташованими у верхній течії рік та ін.); 3) загрози системам життєзабезпечення (сільському і рибному господарству, ресурсам прісної води, лісам і т. ін.); 4) загрози економічному розвитку (дефіцит природних ресурсів, нестабільність фінансової системи і ринків та ін.) $[5,12,16]$.

Особливої уваги заслуговують глобальна динаміка народонаселення і сучасні тенденції розвитку, що реалізуються в умовах, коли рівень цін на енергоносії не стимулює розробки енергоекономних і ресурсозберігальних (маловідхідних) технологій. Посилю- 
ються демографічні контрасти між розвинутими країнами (спад чисельності і збільшення середнього віку населення) і країнами, що розвиваються (зростання чисельності і зменшення середнього віку населення). Процес індустріалізації, що має ключове значення для країн, які розвиваються, породжує значне зростання експлуатації ресурсів біосфери (це, насамперед, стосується вирубування лісів) $\mathrm{i}$ забруднення навколишнього середовища, що виявляється, зокрема, в зростанні концентрації «парникових газів» в атмосфері.

Переважання дешевої сировини як статті експорту з країн, що розвиваються, призводить до зростання їхнього боргу і ще більше посилює глобальну соціально-економічну напруженість. Сформувався складний вузол проблем глобальної безпеки, екологічні, соціально-економічні, політичні та інші аспекти яких виявились нероздільними. Прикладів, що ілюструють цей висновок, дуже багато: зміни клімату і їх вплив на сільське, водне і лісове господарство; кислотні дощі і деградація лісів; зменшення ресурсів і погіршення якості питної води; важко передбачувані наслідки зменшення біорізноманітності та ін. Всі ці процеси стимулюють нестабільність у регіональному і глобальному масштабах. При цьому стає очевидним, що проблеми національної безпеки можуть вирішуватися тільки в контексті глобальної безпеки на основі ефективного планетарного співробітництва. Того ж потребує і вирішення таких проблем, як розширення можливостей володіння ядерною зброєю, а також доступність хімічної й біологічної зброї [5, 16-17].

Запобігання цим загрозам ускладнюється рядом причин: 1) відсутністю достатньо репрезентативних даних спостережень, що характеризують реальні екологічні ситуації; 2) схематичністю імітаційних математичних моделей, призначених для відтворення (i прогнозу) процесів, що відбуваються в природі; 3) фінансовими і науково-технічними можливостями; 4) відсутністю обгрунтованих пріоритетних цілей, черговістю (за важливістю) вирішення цих дуже важливих і взаємопов'язаних проблем.

Важливим кроком в обгрунтуванні пріоритетів стало обговорення в Міжнародному інституті прикладного системного аналізу нового Проекту управління глобальною безпекою і ризиком $[6,212-$ 220]. Виявилось, що це надзвичайно складна проблема. А тому не дивно, що виробити й узгодити конкретні пріоритети людству поки не вдалося. Ще одним важливим кроком у визначенні пріоритетів стала «Друга конференція ООН з навколишнього середовища і ро- 
звитку» (КНСР-2), що відбулася 9-14 червня 1992 р. Вона визначила новий етап на шляху вирішення проблем глобальної екології.

Що ж до масштабів і політичного рівня КНСР-2, то їх безпрецедентність не викликає сумнівів. У Ріо-де-Жанейро зустрілись 114 глав держав, дипломати з 178 країн, представники 1600 неурядових організацій, величезна кількість журналістів. На Конференції було схвалено п’ять основних документів: «Декларація Ріо про навколишнє середовище і розвиток», «Порядок денний-21», який включав угоди про шляхи і засоби здійснення «Заяви про принципи управління, збереження і стійкого розвитку всіх типів лісів»; «Рамкова конвенція $з$ проблеми змін клімату» і «Конвенція з біологічної різноманітності». Прикметно, що підписані 14 червня 1992 р. (в останній день конференції) «Декларація Ріо», «Порядок денний-21» і «Заява про принципи щодо лісів», визначені як документи, що не пов'язують будь-якими зобов'язаннями сторони, які їх підписали.

Заступник Генерального секретаря КНСР-2 Н.Десаі так сформулював основні результати роботи Конференції. Вона: 1) забезпечила сукупність угод між урядами, що ознаменувало значний прогрес міжнародного співробітництва 3 проблем розвитку і навколишнього середовища; 2) забезпечила прийняття угод на найвищому рівні i визнання проблеми усталеного розвитку як ключової в міжнародному дипломатичному порядку денному; 3) відкрила нові шляхи комунікацій і кооперації між офіційними і неофіційними організаціями, які докладають зусиль для вирішення проблем розвитку і навколишнього середовища; 4) привела до суттєвого зростання поінформованості людей про те, що стосується проблем, які обговорювались на конференції [7, 19].

Найбільшим досягненням Конференції був сам процес визнання того факту, що проблеми навколишнього середовища і розвитку вже більше не можуть розглядатися окремо і що проблема стійкого екологічного розвитку є однією з найважливіших. КНСР2 переконливо продемонструвала органічний взаємозв'язок проблем злиднів і слабкого рівня розвитку з екологічними проблемами, як і з умовами (рівнем) життя Півночі (порівняно з Півднем). Споживання енергії і клімат, торгівля тропічною деревиною, проблеми злиднів, зростання населення і опустелювання - всі ці аспекти глобальної і регіональної екології привернули увагу в таких масштабах, які раніше були недосяжними. Важливе значення мало проведення в Ріо паралельного КНСР-2 «Глобального форуму» 
при підтримці великої кількості неурядових організацій (близько 9000 організацій, 29 тис. учасників і 450 тис. відвідувачів, приблизно 1000 засідань і заходів різного типу).

Концепція сталого розвитку знову стала центром уваги політиків світу на новому саміті під егідою ООН, який відбувся восени 2002 року - на цей раз у Йоганнесбурзі (ПАР). Продовжуючи традиції самітів, що відбулися за тридцять і десять років до того, відповідно, у Стокгольмі та Ріо-де-Жанейро, учасники Йоганнесбурзької конференції обговорили проблеми навколишнього середовища та можливі шляхи відповідей на ці проблеми. Були прийняті нові нормативні документи, зокрема «Йоганнесбурзька декларація по сталому розвитку» (04.09.2002) та «Йоганнесбурзький план впровадження» (05.09.2002).

Згідно з цими важливими документами Україна випрацювала свої пріоритети, які включають такі положення:

- утвердження екологічної політики як інтегрованого чинника соціально-економічного розвитку держави, 3 метою переходу до екологічно збалансованого розвитку;

- формування і впровадження екологічно збалансованої системи природокористування, зміни нераціональних моделей виробництва і споживання, еколого-інноваційної модернізації економіки України;

- поліпшення екологічного стану річок, зокрема, басейну Дніпра, та якості питної води;

- стабілізація і поліпшення екологічної ситуації в містах та промислових центрах Донецько-Придніпровського регіону;

- охорона і сталий розвиток Карпат;

- запобігання забрудненню Чорного та Азовського морів, поліпшення їх екологічного стану;

- збереження біотичного та ландшафтного різноманіття, розвиток природно-заповідної справи;

- розширення і зміцнення мінерально-сировинного потенціалу держави, комплексного використання природних ресурсів;

- удосконалення системи задоволення потреб економіки, науки, освіти та оборони країни у геопросторовіи інформації та картографічній продукції;

- реалізація заходів щодо зменшення негативного впливу глобальних екологічних проблем на стан екологічної безпеки країни, розширення участі України у міжнародному співробітництві;

- формування інформаційного простору щодо питань збереження навколишнього середовища, екополітики та сталого розвитку, сприян- 
ня впровадженню системи безперервної екологічної освіти, активне залучення громадськості до вирішення екологічних проблем $[8,78]$.

Безумовно, це дуже важливі питання. І кожне з них може бути пріоритетним. Проте поки що вони - не більше, як побажання чи завдання. Пріоритетними вони стануть тільки тоді, коли під них буде розроблено комплексну програму. Зрозуміло також, що за всієї важливості цих питань дефіцит бюджету не дасть змоги вирішувати ïх одночасно. Тому необхідно встановити черговість їх вирішення. Йдеться не про відкладання якихось екологічних програм на невизначений строк, а про виважену розстановку пріоритетів, які, до речі, кочують щорічно в документах Міністерства, починаючи з 1994 p.

Але цього недостатньо. Треба йти далі - конкретизувати їх, наповнити відповідним змістом, окреслити поетапно, забезпечити науковими, матеріальними і фінансовими ресурсами. Зокрема, хоч у сфері охорони природи задіяні великі сили і заходи, ії концептуальні основи залишаються не досить чіткими. I коли вважають, що для проведення політики екологічно безпечного розвитку потрібна лише добра воля громадян і органів влади, то це - лише умова. Умова необхідна, але недостатня. Наряду з нею потрібні спеціальні знання, які дають змогу орієнтуватися в усій різноманітності природоохоронних проблем, знаходити оптимальні рішення.

Охорона природи, таким чином, не може розглядатись як ізольовна і самодостатня галузь діяльності, вона безпосередньо входить в якості основного компонента в систему загальнолюдських пріоритетів. Цим визначається системний підхід до вирішення природоохоронних проблем, усунення їх уявної конфліктності щодо основних цілей розвитку і загальнолюдської системи цінностей $[4,182]$.

\section{ЛIТЕРАТУРА}

1. Хилько М.I. Екологізація політики. - К., 2004. - 344 с.

2. Экологическая альтернатива: Истоки беды. Знаки беды. - М., 1990. - 800 с.

3. Красилов В.А. Охрана природы: принципы, проблемы, приоритеты. M., 1992. $-173 \mathrm{c}$.

4. Хилько М.І. Екологічна політика. - К., 1999. - 363 с.

5. Концептуальні виміри екологічної свідомості. - К., 2003. - 312 с.

6. Кондратьев К.Я. Глобальная безопасность и ее экологический компонент // Изв. Всес. географ. об-ва. - Т.122. - Вып.3. - 1990. - С.212-220. 
7. Desai N. The outcome of Rio // Network'92. - 1992. - №18. - P.19.

8. Національна доповідь України про гармонізацію життєдіяльності суспільства у навколишньому природному середовищу / Спеціальне видання до 5-ї Всеєвропейської конференції міністрів навколишнього середовища «Довкілля для Свропи». - К., 2003. - 128 с.

Хилько М.І. Класифікація пріоритетів політики екобезпечного розвитку.

Пріоритети політики екологічно безпечного розвитку розглядаються відповідно до просторово-часових масштабів. Це - глобальні, регіональні, національно-державні. Вони можуть бути довготривалі і ситуаційні. Така класифікація досить умовна, адже у більшості випадків все ще відсутні обгрунтовані пріоритетні цілі, черговість вирішення поставлених проблем, слабкість прогнозування і моделювання, фінансового забезпечення. I все ж екологічна загроза, що набирає оберти, вимагає обгрунтованих екологічних пріоритетів. Щодо цього пріоритетність стійкого екорозвитку - одна 3 найважливіших цілей, і зрив ії реалізації прирікає людство на загибель.

Ключові слова: пріоритети, сталий розвиток, екобезпечний розвиток, екологічна криза, екологічні загрози.

Хилько Н.И. Классификация приоритетов политики экобезопасного развития.

Приоритеты политики экологически безопасного развития рассматриваются соответственно пространственно-временным масштабам. Это глобальные, региональные, национально-государственные. Они могут быть долгосрочными и ситуационными. Указанная классификация довольно условная, так как в большинстве случаев все еще отсутствуют обоснованные приоритетные цели, очередность решения поставленных проблем, слабость прогнозирования и моделирования, финансового обеспечения. И все же экологическая угроза, набирающая обороты, требует обоснованных экологических приоритетов. В этом отношении приоритетность устойчивого экоразвития - одна из важнейших целей, и срыв ее реализации обрекает человечество на гибель.

Ключевые слова: приоритеты, устойчивое развитие, экобезопасное развитие, экологический кризис, экологические угрозы.

Khylko N.I. Classification ecosafety development policy priorities.

Policy priorities for environmentally sound development are dealt with spatio-temporal scales. It is - global, regional, national and state. They can be long acting and situational. This classification rather conditional, since in most cases, still no reasonable priorities, prioritize the importance of solving the 
problems, the inadequacy of the environmental monitoring to obtain sufficient data bases, the weakness of forecasting and modeling, financial security. Yet nabirayuchaya turnover environmental threat requires sound environmental priorities. In this regard, the priority of sustainable eco-development - one of the most important goals and the failure to implement it dooms mankind to destruction.

Key words: priorities, sustainable development, environmental safety development, the environmental crisis, environmental threats. 